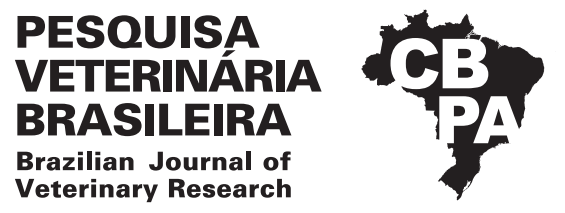

Pesq. Vet. Bras. 39(1):70-74, janeiro 2019 DOI: 10.1590/1678-5150-PVB-5595

Original Article

ISSN 0100-736X (Print)

ISSN 1678-5150 (Online)

\title{
Effects of atracurium besylate on corneal endothelium of chickens: in vitro study ${ }^{1}$
}

\author{
Celeste B. Guimarães ${ }^{2}$, Luciane Albuquerque ${ }^{2}$, Marcela Torikachvili ${ }^{2}$, \\ Eduarda V. Vargas ${ }^{2}$, Cecilia C. Dall'Agnol ${ }^{2}$, Tanise C. Silva ${ }^{2}$ and João A.T. Pigatto ${ }^{2 *}$ (D)
}

\begin{abstract}
Guimarães C.B., Albuquerque L.,Torikachvili M., Vargas E.V., Dall'Agnol C.C., Silva T.C. \& Pigatto J.A.T. 2019. Effects of atracurium besylate on corneal endothelium of chickens: in vitro study. Pesquisa Veterinária Brasileira 39(1):70-74. Faculdade de Veterinária, Universidade Federal do Rio Grande do Sul, Av. Bento Gonçalves 9090, Agronomia, Porto Alegre, RS 91540-000, Brazil. E-mail: pigatto@ufrgs.br

The aim of this study was to investigate the acute effects of atracurium besylate on cellular damage in corneal endothelium of chickens. Twenty healthy chicken eyes were assigned to the following groups: Group 1 (G1), experimental group ( $\mathrm{n}=10$ ); and Group 2 (G2), control $(\mathrm{n}=10)$. Excised corneoscleral buttons were immediately placed on glass microscopy slides with endothelial region faced up. Corneal endothelium of eyes in G1 were covered with $A B$ $(0.2 \mathrm{~mL}, 10 \mathrm{mg} / \mathrm{mL})$ for $3 \mathrm{~min}$ and then rinsed with balanced salt solution (BSS), while the corneal endothelium of eyes in G2 were covered with BBS for 3 min. Corneas from both groups were stained with alizarin red/trypan blue and visualized by light microscopy. Ten random photographs were taken from each cornea. The area of cellular damage was measured by software in all samples and cell loss of each group was averaged and compared. Endothelial area of denudation and Descemet's membrane exposure were higher in G1 than G2. In conclusion, atracurium besylate induced an acute damage on corneal endothelium of chickens.
\end{abstract}

INDEX TERMS: Atracurium besylate, corneal endothelium, chickens, in vitro, avian, mydriasis, damage, alizarin red.

RESUMO.- [Avaliação dos efeitos do besilato de atracúrio no endotélio corneano de galinhas: estudo in vitro.] Objetivou-se avaliar os efeitos agudos do besilato de atracúrio sobre o endotélio corneano de galinhas. Vinte olhos saudáveis de galinhas foram aleatoriamente separados em dois grupos com 10 olhos cada, sendo G1 o grupo controle e G2 o grupo tratamento. Imediatamente após a excisão dos botões corneoesclerais estes foram colocados em lâminas de microscopia de vidro com o lado endotelial voltado para cima. No Grupo 1, o endotélio corneano foi recoberto com $0,2 \mathrm{ml}$ de besilato de atracúrio $(10 \mathrm{mg} / \mathrm{ml})$ durante 3 minutos e depois lavado com solução salina balanceada. No Grupo 2, o endotélio corneano foi recoberto apenas com solução salina balanceada durante 3 min. As córneas de ambos os grupos foram coradas com vermelho de alizarina e azul de tripano e visualizadas com

\footnotetext{
${ }^{1}$ Received on May 2, 2018.

Accepted for publication on July 18, 2018.

${ }^{2}$ Faculdade de Veterinária, Universidade Federal do Rio Grande do Sul (UFRGS), Av. Bento Gonçalves 9090, Agronomia, Porto Alegre, RS 91540-000, Brazil. *Corresponding author: pigatto@ufrgs.br
}

microscópio óptico. Foram obtidas dez fotografias aleatórias de cada amostra. As imagens foram analisadas e com auxílio de um software as áreas com ausência de células endoteliais calculadas. A perda celular endotelial foi significativamente maior no grupo tratamento comparativamente ao grupo controle. Com base nos resultados apresentados foi possível concluir que o besilato de atracúrio induziu dano agudo nas células do endotélio da córnea de galinhas.

TERMOS DE INDEXAÇÃO: Besilato de atracúrio, endotélio corneano, galinhas, in vitro, aves, midríase, córnea, dano endotelial, vermelho de alizarina.

\section{INTRODUCTION}

The corneal endothelium is an interlocking polygonal cell monolayer which comprises the posterior surface of the cornea (Yee et al. 1987). The endothelial integrity and metabolic activities are essential for the maintenance of corneal transparency (Joyce 2012, Albuquerque et al. 2015). Changes in endothelial cells can occur depending on 
age, applied drugs, ocular diseases or intraocular surgical procedures (Gwin et al. 1982, Bercht et al. 2015). Ocular diseases, such as cataracts, are common causes of blindness in birds and surgical treatment are possible and have been implemented with success (Gonçalves et al. 2006, Carter et al. 2007). Neuromuscular blocking agents are used to produce mydriasis in birds, because their iris has striated muscle which is unresponsive to the usual mydriatic and cycloplegic drugs (Oliphant et al. 1983, Barsotti et al. 2012). The use of atracurium as a mydriatic in cataract surgery in birds has been described by some authors as an effective method (Gonçalves et al. 2006, Carter et al. 2007). In these atracurium use reports in intraocular surgery, only intracameral applications have been described. The topical ocular use of neuromuscular blocking agents usually does not cause a sufficient mydriasis. Rocuronium and vecuronium have been successfully used to dilate the pupil of birds. However complications such as corneal ulcer and paralysis of the eyelids were found. (Barsotti et al. 2010a, 2010b, 2012, Petritz et al. 2016).

Among the main methods used for endothelial analysis are specular microscopy, confocal microscopy and scanning electron microscopy (Pigatto et al. 2006, 2008, Nagatsuyu et al. 2014, Kobashigawa et al. 2015, Coyo et al. 2016, Terzariol et al. 2016). In addition, it is possible to analyze and photograph the end othelium of the cornea under an optical microscope after staining with alizarin red dye (Saad et al. 2008, Ruggeri et al. 2009, Park et al. 2012). Endothelial cell loss is inevitable during intraocular surgeries (Terzariol et al. 2016). In this sense, it is important to select substances inert to the endothelium of the cornea in an attempt to avoid endothelial damage that may induce decompensation of irreversible cornea. The intracameral atracurium has been routinely employed to cause mydriasis in birds during intraocular surgery (Gonçalves et al. 2006, Carter et al. 2007). However, the possible effects of this treatment on the corneal endothelium have never been evaluated in birds. The aim of this study was to investigate the acute effects of atracurium besylate on the corneal endothelium of chickens.

\section{MATERIALS AND METHODS}

Twenty corneas from 10 healthy chickens (Gallus gallus domesticus) of the Cobb500 lineage, male and female, with 21 days old, obtained from a local slaughterhouse were studied. All animals were sacrificed for reasons unrelated to this study. The research was conducted according to the Association for Research in Vision and Ophthalmology Statement for the Use of Animals in Ophthalmic and Visual Research. Immediately after humane slaughter enucleation was performed. Ophthalmic examination was realized before the start of the experiment. The examination consisted of evaluation with slit-lamp biomicroscopy (Portable Slit Lamp SL 15, Kowa, Japan) and fluorescein stain (Fluorescein, Allergan, SP, Brazil). Eyes that showed evidence of ocular disease were excluded.

Corneas were randomly divided into two groups of 10 corneas each. Group 1, G1, was the experimental group composed of corneas from the left eyes, and group 2, G2, was the control group composed of corneas from the right eyes. Excised corneoscleral buttons were immediately placed on glass microscopy slides with endothelial region faced up. In G1, the corneal endothelium was covered with $0.2 \mathrm{ml}$ of commercially available atracurium besylate (Cristália, São Paulo, Brazil) for 3 min and then rinsed with balanced salt solution (BSS, Ophthalmos, São Paulo, Brazil). In G2, the corneal endothelium was covered only with BSS for 3 min (Fig.1A). Corneal buttons were placed endothelial side up on a glass slide and stained with $0.1 \%$ trypan blue (Ophthalmos, São Paulo, Brazil) followed by rinsing in BSS and staining with alizarin red (Fig.1B) (Sigma-Aldrich, St Louis, USA) for 90 seconds.

After a final rinse with BSS, the corneal disc was mounted endothelial side up on a microscope slide and examined and photographed using an optical microscope (Nikon Eclipse E200, Japan) at 10x magnification. Ten random images of the corneal endothelium of each cornea were obtained. In each imagine areas with loss endothelial cells were manually measured and quantified using a software for morphometric analysis (UTHSCSA Image tool 3.0, Texas, USA), and then the percentage of endothelial damage was described as mean \pm SD. Statistical data analysis was conducted using Student's t-test using a confidence level of 95\%, in order to check the statistical difference between the level of damage in the treatment eyes (G1) and control eyes (G2).

\section{RESULTS}

With optical microscopy after the use of the dyes in all analyzed images it was possible to observe sharp cellular borders (Fig.1C). In all the analyzed images the areas with absence of cells were idenditified and demarcated (Fig.1D). With this, the percentage of cellular damage was calculated. The results given for endothelial cell loss in the control group were $0.75 \% \pm 1.13 \%$ and in the treatment group were $22.23 \% \pm 13.67 \%$.

The results showed that the average of the level of damage in experimental group was significantly higher than the media of the control group $(\mathrm{p}=0.005)$.

\section{DISCUSSION}

In order to avoid the systemic effects of atracurium, and benefit only from its local action on iridian muscles to generate mydriasis in intraocular surgery, atracurium has been administered intracamerally with satisfactory effects (Gonçalves et al. 2006, Carter et al. 2007). The topical application of atracurium on the cornea has not been described, probably because atracurium has low lipid solubility and, therefore, does not easily penetrate biological membranes. The ocular use of neuromuscular blocking, however, has been reported with the use of other drugs such as rocuronium and vecuronium, producing effective mydriasis in different species of birds, but with some reports of corneal ulcers and transitional eyelid paralysis (Barsotti et al. 2010a, 2010b, 2012, Baine et al. 2016 , Petritz et al. 2016). Gonçalves et al. (2006) applied $0.1 \mathrm{ml}$ of atracurium at a concentration of $10 \mathrm{mg} / \mathrm{ml}$ intracameral in the right eyeballs in 15 chickens of the same age. In the left bulbs, $0.1 \mathrm{ml}$ of normal saline was applied (control group). These authors conclude that the intracameral use of atracurium in chickens produces satisfactory mydriasis for intraocular procedures without clinical signs of systemic or contralateral effects. However, the ophthalmologic examination was performed only with focused light, which showed conjunctiva with no detectable evidence of inflammation, transparent chambers and a normal iridian movement, but no tools were used for more accurate evaluation, such as corneal pachymetry or microscopy techniques. Therefore, it was not possible to state the absence of endothelial damage. 

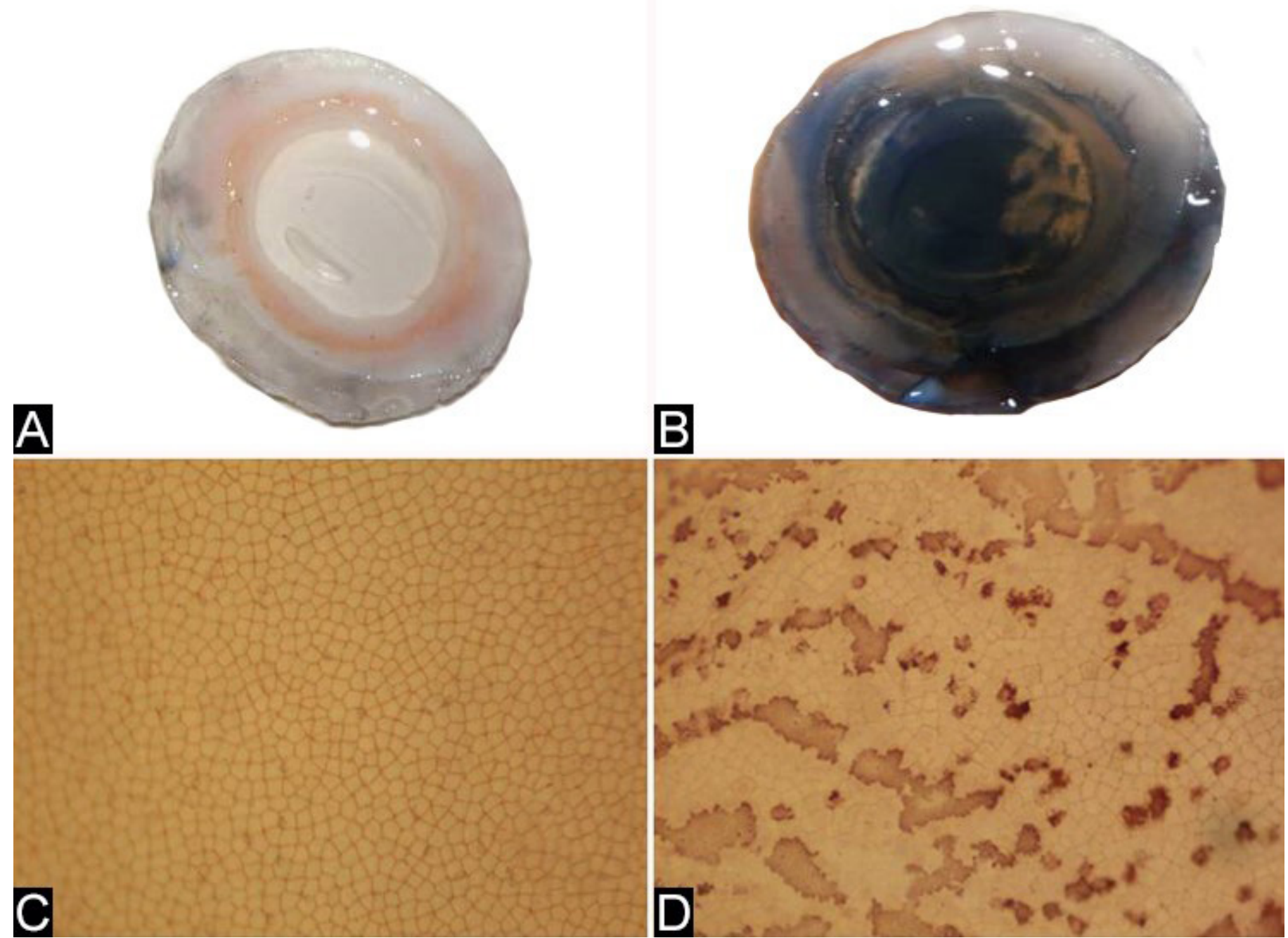

Fig.1. (A) Excised corneoscleral button of chicken eye with the endothelial side face up covered with BSS. (B) Corneoscleral button with the endothelial side face up after staining with trypan blue and alizarin red. (C) Optical photomicrograph of corneal endothelium from G2 stained with alizarin red. The endothelium has a regular polygonal appearance. Obj.10x. (D) Optical photomicrograph of experimental corneal endothelium stained with alizarin red showing areas of cell loss. Obj.10x.

Among used techniques to analyze the corneal endothelium are including mainly SEM, specular microscopy, and optical microscopy (Pigatto et al. 2006, 2008, Nagatsuyu et al. 2014, Kobashigawa et al. 2015, Coyo et al. 2016, Faganello et al. 2016).

SEM has been applied mainly for the analysis of endothelial cell ultrastructure of different species of animals and to evaluate the effects of medications, chemicals or surgical procedures on the endothelium (Pigatto et al. 2009, Tamayo-Arango et al. 2009, Terzariol et al. 2016). Specular microscopy is the technique most used for clinical evaluations in humans and animals (Pigatto et al. 2006, 2008, Franzen et al. 2010, Nagatsuyu et al. 2014, Albuquerque et al. 2015, Bercht et al. 2015, Kobashigawa et al. 2015, Coyo et al. 2016). Among the limitations of specular microscopy technique is the difficulty of obtaining images in corneas that are not transparent (Saad et al. 2008). The evaluation method of the corneal endothelium through the use of vital staining enables a simple, fast and convenient way to detect cell damage (Taylor \& Hunt 1981, Faganello et al. 2016). This technique was applied in this study using alizarin red and trypan blue dyes and it has demonstrated to be a protocol that can be used to stain the corneal endothelium of chickens, since clear images were obtained of the endothelial monolayer. The alizarin red dyes the intercellular spaces and exposure of Descemet's membrane in areas where cell loss occurs, and the trypan blue stains the nuclei of dead cells, where the cell membrane is not intact (Saad et al. 2008). Some species of birds have had their corneal endothelium studied in relation to endothelial cell density, area, shape and cell morphology (Yee et al. 1987, Pigatto et al. 2009). Albuquerque et al. (2015) studied the corneal endothelium of chickens from different age groups by specular microscopy, which showed a regular pattern in the distribution of cells. The corneal endothelium of chickens was similar to that of other vertebrate species. Thus, the importance of the subject, coupled with the lack of data about the impact of atracurium besylate in the corneal endothelium, motivated this study. Despite there being no reports about cataract removal surgery in chickens, this becomes a viable model to investigate because of its corneal endothelium similarities with other species of birds. 
The option of an ex vivo study using chicken's eyes from the slaughter line was a viable alternative, particularly from an ethical point of view, since avoided the death of animals for reasons relating solely to this research. Previous studies with enucleated eyes proved it is possible to analyze the cornea within six hours postmortem without structural changes occurring in the endothelium (Pigatto et al. 2008, 2009, Terzariol et al. 2016). The samples were divided into two groups, the experimental group consisting of the left eyes and the control group consisting of the right eyes. Previous studies reported a lack of differences regarding endothelial parameters obtained from the right and left eyes (Pigatto et al. 2008, 2009, Terzariol et al. 2016). Therefore, the evaluation of one eye allowed us to infer the same results for the contralateral eye. The existence of the control group is critical for the study since it evaluates the endothelium after handling performed in the processes of enucleation of the eye and excising the corneoscleral button. This analysis later helped in the statistical calculation to differentiate the damage caused by atracurium and manipulation, which would not be possible with a previous endothelial analysis with specular microscopy before the excision of buttons, for example. In this experiment it was possible to evaluate immediate effects in the chicken's corneal endothelium caused by exposure to atracurium in all corneas of G1. The areas of cell loss and endothelial denudation with Descemet's membrane exposure were stained by alizarin red. The corneas of $\mathrm{G} 2$ also had areas stained with alizarin red. The technique used for corneal excision and handling during the staining procedure can be responsible for those areas of cell loss. Corneal endothelial toxicity is related to substances that come in contact with the endothelium, based on their chemical compositions, pH and osmolarities (Edelhauser et al. 1981, Carter et al. 2007). The $\mathrm{pH}$ of atracurium besylate is 3.25 to 3.65 , and its osmolarity is $10-30 \mathrm{m0sm} / \mathrm{L}$ which is below the range tolerated by the corneal endothelium in tested species. Therefore, the fact that it is acidic and hyposmotic relative to the aqueous humor can explain its toxic effect. The results of the present investigation as it was performed showed that atracurium induced significant damage in the cells of the endothelium of the cornea of chickens. It is important to emphasize that in the current study atracurium was placed in direct contact with the corneal endothelium of chickens for three minutes. When used intracameral the atracurium will be diluted by the aqueous humor and probably the endothelial damage will be smaller than that evidenced in the present study. In addition, the results obtained in the current study are related to the acute effect of atracurium on the corneal endothelium of chickens. The observed endothelial changes were not correlated with functional impairment of the endothelium. In this sense, future research evaluating the corneal endothelium using live animals after intracameral atracurium injection is necessary to elucidate these facts.

\section{CONCLUSION}

The results obtained with this research indicated that atracurium bezilate induced an acute damage on corneal endothelium of chickens.

Acknowledgements.- We thank agronomic experimental station of Federal University of Rio Grande do Sul for supplying the eyes used in this research.

Conflict of interest statement. - The authors have no competing interests.

\section{REFERENCES}

Albuquerque L., Freitas L.V.R.P. \& Pigatto J.A.T. 2015. Analysis of the corneal endothelium in eyes of chickens using contact specular microscopy. Semina, Ciênc. Agrárias 36(6):4199-4206.

Baine K., Hendrix D.V.H., Kuhn S.E., Souza M.J. \& Jones M.P. 2016. The efficacy and safety of topical rocuronium bromide to induce bilateral mydriasis in hispaniolan amazon parrots (Amazona ventralis). J. Avian. Med. Surg. 30(1):8-13. <http://dx.doi.org/10.1647/2015-083> <PMid:27088739>

Barsotti G., Briganti A., Spratte J.R., Ceccherelli R. \& Breghi G. 2010a. Bilateral mydriasis in common buzzards (Buteo buteo) and little owls (Athene noctua) induced by concurrent topical administration of rocuronium bromide. Vet. Ophthalmol. 13(Suppl.1):35-40.<http://dx.doi. org/10.1111/j.1463-5224.2010.00808.x><PMid:20840082>

Barsotti G., Briganti A., Spratte J.R., Ceccherelli R. \& Breghi G. 2010b. Mydriatic effect of topically applied rocuronium bromide in tawny owls (Strix aluco): comparison between two protocols. Vet. Ophthalmol. 13(Suppl.1):9-13 <http://dx.doi.org/10.1111/j.1463-5224.2010.00773.x><PMid:20840085>

Barsotti G., Briganti A., Spratte J.R., Ceccherelli R. \& Breghi G. 2012. Safety and efficacy of bilateral topical application of rocuronium bromide for mydriasis in european kestrels (Falco tinnunculus). J. Avian. Med. Surg. 26(1):1-5. <http://dx.doi.org/10.1647/2011-002.1><PMid:22645832>

Bercht B.S., Albuquerque L., Araujo A.C. \& Pigatto J.A.T. 2015. Specular microscopy to determine corneal endothelial cell morphology and morphometry in chinchillas (Chinchilla lanigera) in vivo. Vet. Ophthalmol.18(Suppl.1):137-142. <http://dx.doi.org/10.1111/vop.12236><PMid:25469785>

Carter R.T., Murphy C.J., Stuhr C.M. \& Diehl K.A. 2007. Bilateral phacoemulsification and intraocular lens implantation in great horned owl. J. Am. Vet. Med. Assoc. 230(4):559-561. <http://dx.doi.org/10.2460/javma.230.4.559> <PMid:17302557>

Coyo N., Peña M.T., Costa D., Ríos J., Lacerda R. \& Leiva M. 2016. Effects of age and breed on corneal thickness, density, and morphology of corneal endothelial cells in enucleated sheep eyes. Vet. Ophthalmol.19(5):367-372. <http://dx.doi.org/10.1111/vop.12308><PMid:26338229>

Edelhauser H.F., Hanneken A.M., Pederson H.J. \& Van Horn D.L. 1981. Osmotic tolerance of rabbit and human corneal endothelium. Arch. Ophthalmol 99(7):1281-1287.<http://dx.doi.org/10.1001/archopht.1981.03930020155021> $<$ PMid:7259603>

Faganello C.S., Silva V.R.M., Andrade M.C.C., Carissimi A.S. \& Pigatto J.A.T. 2016. Morphology of endothelial cells from different regions of the equine cornea. Ciência Rural 45(12):2223-2228. <http://dx.doi.org/10.1590/01038478cr20160216>

Franzen A.A., Pigatto J.A.T., Abib F.C., Albuquerque L. \& Laus J.L. 2010. Use of specular microscopy to determine corneal endothelium cell morphology and morphometry in enucleated cat eyes. Vet. Ophthalmol. 13(4):222-226 <http://dx.doi.org/10.1111/j.1463-5224.2010.00787.x><PMid:20618799>

Gonçalves G.F., Pachaly J.R., Pippi N.L., Romagnolli P., Belettini S.T. \& Neves A.G. 2006. Facectomia extracapsular em avestruz (Struthio camelus Linnaeus, 1758): relato de caso. Revta Port. Ciênc. Vet. 101(559):295-297.

Gwin R.M., Lerner I., Warren J.K. \& Gum G. 1982. Decrease in canine corneal endothelium cell density and increase in corneal thickness as functions of age. Invest. Ophthalmol. Vis. Sci. 22(2):267-271. <PMid:7056641>

Joyce N.C. 2012. Proliferative capacity of the corneal endothelium. Exp. Eye. Res. 95(1):16-23. <http://dx.doi.org/10.1016/j.exer.2011.08.014> $<$ PMid:21906590>

Kobashigawa K.K., Lima T.B., Padua I.R.M., Sobrinho A.A.F.B., Marinho F.A., Ortêncio K.P. \& Laus J.L. 2015. Ophthalmic parameters in adult Shih Tzu dogs. Ciência Rural 45(7):1280-1285. <http://dx.doi.org/10.1590/01038478cr20141214>

Nagatsuyu C.E., Abreu P.B.A., Kobashigawa K.K., Conceição L.F., Morales A., Andrade A.A., Padua I.R.M., Martins B.C. \& Laus J.L. 2014. Non-contact 
specular microscopy in aphakic and pseudophakic dogs. Ciência Rural 44(4):682-687. <http://dx.doi.org/10.1590/S0103-84782014000400018>

Oliphant L.W., Johnson M.R., Murphy C. \& Howland H. 1983. The musculature and pupillary response of the great horned owl iris. Exp. Eye. Res. 37(6):583-595. <http://dx.doi.org/10.1016/0014-4835(83)90134-3> $<$ PMid:6662207>

Park S., Fong A.G., Cho H., Zhang C., Gritz D.C., Mian G., Herzlich A.A., Gore P., Morganti A. \& Chuck R.S. 2012. Protocol for vital dye staining of corneal endothelium cells. Cornea 31(12):1476-1479. <http://dx.doi.org/10.1097/ ICO.0b013e31824d0dda > <PMid:22531436>

Petritz O.A., Guzman D.S., Gustavsen K., Wiggans K.T., Kass P.H., Houck E., Murphy C.J. \& Paul-Murphy J. 2016. Evaluation of the mydriatic effects of topical administration of rocuronium bromide in hispaniolan amazon parrots (Amazona ventralis). J. Am. Vet. Med. Assoc. 248(1):67-71.<http:// dx.doi.org/10.2460/javma.248.1.67><PMid:26684093>

Pigatto J.A.T., Abib F.C., Pereira G.T., Barros P.S.M. \& Laus J.L. 2006. Density of corneal endothelial cells in eyes of dogs using specular microscopy. Braz. J. Vet. Res. Anim. Sci. 43(4):476-480. <http://dx.doi.org/10.11606/ issn.1678-4456.bjvras.2006.26462>

Pigatto J.A.T., Cerva C., Freire C.D., Abib F.C., Bellini L.P., Barros P.S.M. \& Laus J.L. 2008. Morphological analysis of the corneal endothelium in eyes of dogs using specular microscopy. Pesq. Vet. Bras. 8(9):427-430. <http:// dx.doi.org/10.1590/S0100-736X2008000900006>

Pigatto J.A.T., Franzen A.A., Pereira F.Q., Almeida A.C.V.R., Laus J.L., Santos J.M., Guedes P.M. \& Barros P.S.M. 2009. Scanning electron microscopy of the corneal endothelium of ostrich. Ciência Rural 39(3):926-929. <http:// dx.doi.org/10.1590/S0103-84782009005000001>
Ruggeri A., Scarpa F., De Luca M., Meltendorf C. \& Schroeter J. 2009. A system for the automatic estimation of morphoemtric parameters of corneal endothelium in alizarine red-stained images. Brit. J. Ophthalmol. 94(5):643647. <http://dx.doi.org/10.1136/bjo.2009.166561>

Saad H.A., Terry M.A., Shamie N., Chen E.S., Friend D.F., Holiman J.D. \& Stoeger C. 2008. An easy and inexpensive method for quantitative analisys of endothelial damage by using vital dying staining and adobe photoshop software. Cornea 27(7):818-824.<http://dx.doi.org/10.1097/ ICO.0b013e3181705ca2><PMid:18650669>

Tamayo-Arango L.J., Baraldi-Artoni S.M., Laus J.L., Vicenti F.A.M., Pigatto J.A. \& Abib F.C. 2009. Ultrastructure, morphology and morphometry of a normal corneal endothelium of adult crossbread pig. Ciência Rural 9(1):117-122. <http://dx.doi.org/10.1590/S0103-84782009000100018>

Taylor M.J. \& Hunt C.J. 1981. Dual staining of corneal endothelium with tripan blue and alizarin red S: importance of $\mathrm{pH}$ for the dye-lake reaction. Brit. J. Ophthalmol. 65(12):815-819.<http://dx.doi.org/10.1136/bjo.65.12.815> <PMid:6172144>

Terzariol M., Hünning P.S., Brambatti G., Albuquerque L., Neumann C. \& Pigatto J.A.T. 2016. Effects of intracameral brilliant blue on the corneal endothelium of swine: in vitro study. Pesq. Vet. Bras. 36(8):775-780. <http://dx.doi.org/10.1590/S0100-736X2016000800016>

Yee R.W., Edelhauser H.F. \& Stern M.E. 1987. Specular microscopy of vertebrate corneal endothelium: a comparative study. Exp. Eye Res. 44(5):703-714. <http://dx.doi.org/10.1016/S0014-4835(87)80141-0><PMid:3497816> 